\title{
ECLETISMO E PLURALIDADE CULTURAL NA PASSAGEM DO SÉCULO XIX PARA O SÉCULO XX
}

\section{ECLECTICISM AND CULTURAL PLURALITY AT THE TURN OF THE 20TH CENTURY}

\author{
Recebido: 15/05/2020 | Aprovado: 17/06/2020 | Publicado: 10/07/2020 \\ DOI: https://doi.org/10.18817/rlj.v4i1.2303
}

Frederico Augusto Liberalli de Goes ${ }^{1}$

Orcid ID: https://orcid.org/0000-0001-9989-2579

\begin{abstract}
Resumo: A virada do século XIX para o XX até a Semana de Arte Moderna foi um momento ímpar na produção cultural e literária brasileiras. Este artigo objetiva destacar figuras importantes, mas esquecidas, da cena intelectual carioca daquele período, como o jornalista Alberto Figueiredo Pimentel, que registrou em suas colunas importantes fatos daquela sociedade, além de ser o pioneiro escritor da literatura infantil. O texto coloca seu foco também nos salões onde se reuniam a intelectualidade da época, além de importantes expoentes da música popular brasileira, como Pixinguinha e Heitor dos Prazeres. Cartografia daquela cena intelectual, este artigo demonstra a profícua produção daquela geração carioca, muitas vezes invisibilizada, possibilitando assim uma abertura para outros inúmeros questionamentos.
\end{abstract}

Palavras-chave: Alberto Figueiredo Pimentel. art nouveau. literatura. salões. música brasileira.

Abstract: The turn of the 19th to the 20th century until the Modern Art Week was a moment unique in Brazilian cultural and literary production. This article aims to highlight importante, but but forgotten figures of Rio's intellectual scene of that period, as the journalist Alberto Figueiredo Pimentel, who recorded in his columns important facts about that society, besides being the pioneer writer of children's literature. The text also focuses on salons where the intellectuals of the time met, as well as important exponents of popular music such as Pixinguinha and Heitor dos Prazeres. Cartography of that intellectual scene, this article demonstrates the fruitful production of that carioca generation, often invisible, allowing an opening for countless other questions.

Keywords: Alberto Figueiredo Pimentel. art nouveau. literature. salons. Brazilian music.

Neste dossiê, dirige-se a atenção ao período que compreende a passagem do século XIX para o século XX, até a chegada de 1920, década em que se convencionou identificar como marco do modernismo, e denominada, em Paris, les années folles (anos loucos), o Pós-Grande Guerra. Como as viradas de séculos parecem pôr em xeque o status quo e oferecer novas perspectivas para a revisão de velhos paradigmas (basta lembrar o "renascer" que se dá na passagem do

\footnotetext{
${ }^{1}$ Graduado em Português e Literaturas Brasileira e Portuguesa/UFRJ, mestre em Sistemas de Comunicação/UFRJ e doutor em Teoria Literária/UFRJ. Atualmente é professor Titular do Departamento de Ciência da Literatura da Universidade Federal do Rio de Janeiro. Tem experiência na área de Letras, com ênfase em Teoria Literária, atuando principalmente nos seguintes temas: cultura brasileira, literatura brasileira, carnaval, música popular brasileira e teoria literária. E-mail: fredgoes3@gmail.com
} 
século XV para o XVI), busca-se, aqui, compreender essa fase tão complexa, eclética e plural que se acordou denominar sob o medonho e impreciso conceito de protomodernismo. Para tanto, utiliza-se, como protagonista deste texto, um personagem obscurecido pela história cultural brasileira, mas que teve papel de destaque no universo intelectual de então: o polígrafo Alberto Figueiredo Pimentel (1869-1914).

Há que se sublinhar que a atenção está aqui dirigida para o que se passava na então Capital Federal.

A escolha do personagem tem por objetivo dar relevo à pluralidade do período, toscamente denominado sob um conceito genérico. Possivelmente, em face a um cacoete didático, costuma-se confinar momentos, espaços de tempo em movimentos sempre que se observam aspectos comportamentais, visões de mundo, recorrências estéticas comuns e, em muitos casos, quando há um documento (manifesto) no qual se enumeram as linhas gerais do pensamento de grupos. Ocorre, no entanto, que há fases menos gregárias, em que se percebe uma maior diversidade de atitudes e percepções, convivendo contemporaneamente. Quando Figueiredo Pimentel é nomeado polígrafo, tem-se como propósito exemplificar esta passagem de século por meio de alguém que, como o termo define, se caracterizou pela escrita plural.

De forma tão suscinta, quanto precisa, Ruy Castro (2019), no parágrafo inicial do primeiro capítulo de seu livro sobre o momento aqui enfocado, observa sobre a multiplicidade de novidades com que os primeiros anos do século XX se depararam:

Em 1920, o mundo já tinha o cinema, o fonógrafo, a eletricidade, o automóvel, o avião, a teoria da relatividade, a aspirina, a cocaína, a psicanálise , o raio $X$, o arranha-céu, o futebol, o batom, a gilete , a Revolução Russa, o fascismo, o feminismo, o dodecafonismo, o cubismo, o futurismo, o dadaísmo, o expressionismo e dezenas de outros ismos, gerando inclusive je-m'en-fichismo _ não estar nem aí _ diante de tantas novidades. Atitude essa que não passava de teatro, porque era impossível ficar indiferente ao que as grandes cidades, de súbito, tinham de moderno a oferecer.

O Rio era uma delas. 2

${ }^{2}$ CASTRO,Ruy. (2019) p.31

*Somamos ao que enumera Ruy Castro que até os anos de 1920, o mundo vivera ainda a Grande Guerra (1914-1919) e, antes do término desta, a devastadora gripe espanhola que, hoje, se estima ter matado entre 20 milhões e 50 milhões de pessoas. 
É curioso que um indivíduo que teve extrema importância na vida da cidade do Rio de Janeiro, na passagem do século XIX para o XX e nos primeiros anos deste, tenha caído em completo esquecimento em uma centúria. Jornalista, cronista, poeta, romancista, contista que vivia no olho do furacão da vida intelectual e social da então capital federal foi relegado ao "oblívio", a morada do esquecimento. Em 2014, fez cem anos que Alberto Figueiredo Pimentel faleceu. A única celebração realizada em sua homenagem foi $A$ Jornada Figueiredo Pimentel, um polígrafo na Primeira República, uma iniciativa do Centro de Letras e Artes da Universidade Federal do Rio de Janeiro e da Fundação Biblioteca Nacional, em agosto daquele ano. A nós coube, na ocasião, apresentar uma palestra sobre a relação dele com o carnaval carioca e sua renomada elegância na sociedade carioca. A partir deste encontro, organizou-se o livro Figueiredo Pimentel, um polígrafo da Belle Époque (2019).

Figueiredo Pimentel nasceu em Macaé em 11 de outubro de 1869 e faleceu no Rio de Janeiro em 05 de fevereiro de 1914, aos 45 anos. Com a idade de dezessete se iniciou no jornalismo. Foi o primeiro intelectual brasileiro a se preocupar em popularizar o livro, através de edições mais acessíveis de autores clássicos.

Pimentel reuniu em 1896, Contos da Carochinha, 61 contos populares, morais e proveitosos, de vários países, traduzidos ou recolhidos diretamente da tradição oral entre eles Histórias da Avozinha; Histórias da Baratinha; Contos de Fadas; Contos do Tio Alberto; Histórias do Arco da Velha. Nessa recolha, há contos de Perrault, Grimm e Andersen; fábulas; apólogos; alegorias; contos exemplares; lendas; parábolas; provérbios; contos jocosos; etc. As publicações infantis eram encomendadas pelo editor Pedro da Silva Quaresma, dono da Livraria do Povo, que se destacava, na cena das livrarias e das casas editoriais do princípio do século XX, no Rio de Janeiro, pelo fato de ser um dos poucos donos de uma livraria e editora brasileiras, em um ambiente dominado pelos Garnier (francês), os Francisco Alves (português), os Laemmert (alemão).

A importância de Figueiredo Pimentel no cenário da literatura infantil é extraordinária, tanto pelo fato de possibilitar a leitura aos pequenos leitores em livros a preços accessíveis, como, e, principalmente, por escrever histórias 
aclimatadas no Brasil e em português falado no Brasil. Antes das publicações de Pimentel, as crianças pouco entendiam os textos escritos em português de Portugal, carregados de expressões inusuais no falar brasileiro, às quais os jovens leitores não estavam familiarizados.

É da lavra de Pimentel, e, também, encomenda de Quaresma, o popularíssimo entre as moçoilas, Manual dos Namorados, em que eram sugeridas técnicas de sedução e conquista. Anteriormente, à produção de livros infantis, publicou, em 1893, o livro de poesias, Fototipias, inscrevendo-se na primeira leva dos simbolistas vanguardeiros. Foi correspondente do Mercure de France, quartel general dos simbolistas franceses, onde escrevia as Lettres Bresiliennes, sob o pseudônimo de Barão de Santo Alberto. Em prosa, no mesmo ano, lança o romance naturalista $O$ Aborto, popular, escandaloso, considerado pornográfico, entre outras obras como O Suicida, de grande sucesso, e O terror dos Maridos, Um Canalha, Livro Mau. Como se observa, os temas e os títulos das obras eram estrategicamente escolhidos para atiçarem a curiosidade do público, prenunciando os artifícios mercadológicos utilizados nos lançamentos dos Best Sellers contemporâneos. Temas como sexo, drogas, censura e política eram recorrentes tanto nas páginas diárias quanto nas literárias. E, não eram só os escritores que causavam calafrios morais. Poetas como Gilka Machado, eram consideradas devassas, cujo principal propósito, aos olhos de um expressivo número de leitores e mesmo de certos críticos, era épater la bourgeoisie.

A coluna mundana Binóculo, comandada por Pimentel entre os anos de 1907 e 1914, na Gazeta de Notícias, tinha grande vivacidade, bom ritmo e, por sua própria dinâmica, se estruturava em flashes (notas), fragmentos diversos, ainda que, frequentemente, quando um tema merecia maior atenção do colunista, ganhasse os contornos da crônica. Um recurso usado com regularidade para ambientar o leitor no dia enfocado era iniciar o texto com a descrição do tempo (crônos). Observa o autor tratar-se ou não de um dia bonito, como se apresentava o céu como bem se pode aquilatar nos exemplos selecionados:

Dia de chuva. Dia tristíssimo. Chove desde a madrugada, e continuou com mais ou menos intermitência, pelo dia adiante. Também era um dia morto. A chuva até foi boa. Refrescou o tempo. Quarta-Feira de Cinzas. ${ }^{3}$

${ }^{3}$ PIMENTEL, Figueiredo. Binóculo. Gazeta de Notícias. Rio de Janeiro 5/03/1908 p.1 
Dia sombrio de mormaço. Foi com surpresa que a população carioca despertou. Receava-se chuva. Isto é, transferência da Batalha de Confetti, da Festa dos Cordões. E o receio foi justificado. Choveu. Tudo transferido. Que pena! ${ }^{4}$

F. Pimentel finaliza a coluna deste mesmo dia novamente com pesar.

A chuva impediu a realização da Batalha de Confetti. Devia estar lindo esse lindíssimo e chic divertimento. Foi uma calamidade. Como binocular numa segunda-feira de Carnaval, toda molhada?!...Impossível. ${ }^{5}$

Observe-se que o fato lamentado é a suspensão da batalha de confete empreendida pelas classes mais favorecidas. A ideia de Festa dos Cordões, expressão popular, ganha aqui conotação genérica do carnaval realizado em espaço público, não definindo o segmento social.

Binóculo era o termômetro comportamental da elite social que buscava estar up-to-date com as novidades de Paris e Londres. O que era sugerido na coluna era incorporado com tal rapidez e obediência que, por ocasião da inauguração do Teatro Municipal, em 1909, não paravam de chegar cartas à redação da Gazeta e senhoras e senhoritas mais aflitas iam pessoalmente se consultar com Pimentel sobre como se vestir, que acessórios usar na cerimônia inaugural. Em função de suas descrições minuciosas dos trajes das damas das altas rodas em sua coluna, há quem suponha ter sido também figurinista, já que seu olhar afiado e refinado distinguia sem titubear quem estava atento às novidades parisienses. Todas as quintas-feiras à tarde, perto da Travessa do Ouvidor, no epicentro da elegância carioca, à porta das redações das principais folhas diárias, acontecia um verdadeiro desfile das coquetes. Os juízes eram Figueiredo Pimentel e seu séquito, do qual fazia parte Paulo Barreto, o João do Rio. As observações de Pimentel, em estilo muito próprio e um tanto pernóstico, eram aguardadas com ansiedade pelos leitores da coluna. Vale sublinhar que àquela altura as notícias chegavam às redações, não se ia em busca delas. Quem efetivamente revolucionou a prática jornalística neste sentido foi João do Rio que enquanto

4PIMENTEL, Figueiredo. Binóculo. Gazeta de Notícias. Rio de Janeiro 8/03/1908 p.3 5idem 
flanava pela cidade, pelos mais diversos rincões, se alimentava da "alma encantadora das ruas" cariocas.

A Gazeta de Notícias era um jornal de elite que tinha um público fiel e que contava no seu quadro de redatores com os intelectuais e jornalistas mais destacados então. Eram eles Guimarães Passos, Olavo Bilac, Emílio Menezes, Pedro Rabello, Viriato Correia, Paulo Barreto (João do Rio), entre outros. A partir de 1907, ano que é iniciada a coluna Binóculo, se torna a mais moderna das folhas diárias. Oferece um maior número de ilustrações coloridas e mesmo fotos, caras e raras ainda, suplementos literários, entre outras novidades. Como jornal moderno que era, tinha a necessidade de contar com um apologista das reformas empreendidas na cidade durante o governo de Rodrigues Alves, a partir de 1904, e que teve nas figuras do prefeito Pereira Passos e de Oswaldo Cruz seus mais destacados representantes. O apologista em referência era o poeta e cronista Olavo Bilac. Mas, fazia-se ainda necessária uma seção que indicasse o que estava em acordo com a vida moderna, como se comportar e viver na "metrópole", neste caso a responsabilidade recaia sobre Figueiredo Pimentel que desempenhou este papel com grande desenvoltura, informando aos leitores como exercitar a vida metropolitana "smart". É dele, por exemplo, a máxima que se torna o slogan da modernização da cidade "o Rio civiliza-se", como é também, "a ditadura do smartismo", que se refere ao modo "descolado", atualizado de viver e circular pelos lugares "certos" da cidade.

Um aspecto curioso a se ressaltar, e que se soma a pluralidade de facetas de F. Pimentel, é o fato de ele ser quem, por um lado, determina como a elite deve se comportar nos bairros elegantes como Botafogo e Laranjeiras, ser ele um dândi na mais completa acepção, e, por outro, ser morador de um subúrbio modesto e distante, Todos os Santos, o mesmo onde moravam Lima Barreto e o, então, menino Orestes Barbosa. Na biografia de Orestes Barbosa, Carlos Didier ${ }^{6}$ observa o encantamento que Pimentel provocava no garoto Orestes quando o jornalista, por volta dos seus 36 anos, saltava do trem no subúrbio onde moravam. Subúrbio, cujo nome, parece revelar ser espaço que acolhe gente de níveis sociais diversos, 
Todos os Santos. Descreve-nos, Didier, a cena da chegada de Pimentel à estação ferroviária suburbana:

Pimentel, todos os dias, salta do trem e entra na (rua) José Bonifácio a caminho de casa: jaquetão, chapéu de palhinha, monóculo e luvas; bigode, pera e barbinha bifurcada em cauda de pássaro, testa larga, olhos mortiços e nariz reto; polainas cor de cinza expostas ao barro das ruas.

O ansioso desejo da elite de transformar o Rio de Janeiro em uma Paris tropical, civilizada e moderna se deparava com uma realidade prenhe de contrastes em todos níveis. Na mesma cidade em que se liam nos jornais notícias rebordadas de galicismos, em que abundavam palavras e expressões francesas, a porcentagem de analfabetos era escabrosa. Só no Rio de Janeiro, capital da república, em 1906, eram de 76,9\%. A explosão demográfica da cidade no final do século XIX fez com que a população saltasse de 266 mil para 730 mil habitantes entre 1872 e 1904, com a chegada de ex-cativos ( após a abolição , 34\% da população era negra ou mestiça) e de imigrantes (os quais chegavam a perfazer $40 \%$ da força de trabalho da capital federal), consequentemente, inchando, sobretudo, os cortiços e as favelas que começam a subir os morros do centro da cidade. Este dado é importante para pensarmos o contingente populacional que representava a classe trabalhadora e o impacto sociocultural provocado por esta gente, justo, no momento, em que se buscava fazer do Rio a nouvelle Paris.

É surpreendente que, diante do quadro acima, a incidência do uso de estrangeirismos nas folhas diárias fosse, de tal monta, que pareciam ser publicações biligues. Certa feita, o cronista carnavalesco, Mauro de Almeida, famoso por ser o letrista que assina com Donga "Pelo Telefone", (o primeiro registro do gênero samba, em 1916), e conhecido com Peru dos Pés Frios, satiriza a fala híbrida utilizada por Figueiredo Pimentel em Binóculo. Ele intitula de Binóculo Carnavalesco, sua coluna no Diário Carioca, onde carnavaliza o padrão estético cosmopolita do janota smart, ridicularizando o pseudo smartismo das personagens políticas da época, conforme destaca Eduardo Granja Coutinho (2006) 7 :

Antônio Prado Junior, C'est monsieur le Prefect... Oh, II y a une elegance incomparable et um aplomb de la statue du marechal de fer (...). Sábado,

\footnotetext{
${ }^{7}$ COUTINHO, Eduardo Granja (2006) p. 117
} 
il a passe avec monsieur Gerimaire Dantas pour s'en aller a voir tous les buraques que monsieur Agache a esburaque dans la praia de la Lapa(...).

Entre os letrados, conhecer a língua francesa com desenvoltura era uma obrigatoriedade. Como informa Ruy Castro (2019) ${ }^{8}$ :

\begin{abstract}
Anatole France, Ernest Renan e Émile Zola eram tão populares aqui quanto José de Alencar. Cozinhava-se e comia-se à francesa. Vestia-se à francesa. Amava-se à francesa _ o beijo de língua era o "beijo francês". Tudo que era novo parecia vir da França: o cinema, a bicicleta, a fotografia, os perfumes, a maquiagem, as escolas poéticas, as correntes filosóficas, o confete, a serpentina e os bals masques do Carnaval. Partituras das valsas como "Frou-Frou", "Amoureuse" e "Fascination" estavam em todos os pianos. A tudo se brindava com champanhe.
\end{abstract}

Tendo como a referência, a figura de Figueiredo Pimentel, seguimos na tentativa de esboçar o cenário das letras daquele momento, jogando luz no que parece relevante como indicativo da pluralidade estética e, sobretudo, pinçando alguns personagens e acontecimentos que a história empalideceu, em consonância ao que se propõe este número de JUSSARA.

Nesta passagem de século, estão presentes luminares das nossas letras como Lima Barreto, Olavo Bilac, Machado de Assis, tão diferente entre eles. Machado incomparável sempre, até seus dias finais, em setembro de 1908. Todos estes escritores foram aquinhoados com fortunas críticas respeitáveis, daí, quando muito, aparecerem aqui como figurantes en passant, em determinadas cenas. Registremos em nossas memórias que a Academia Brasileira de Letras é fundada em 1897. De 1888, Abolição da Escravidão, 1889, Decretação da República, até o final da Primeira Grande Guerra, 1919, há um verdadeiro frenesi de acontecimentos.

Recorremos, ainda uma vez, a Ruy Castro $(2019)^{9}$, para fixar os contornos da paisagem literária daquele momento em que os contrastes se reforçam:

Era um mundo literário. A informação vinha pela palavra, nos jornais, revistas, livros debates e conferências. Mesmo a caricatura, principal imagem numa imprensa ainda escassa em fotografias, era um afluente da palavra _ raras as charges sem legendas.

\footnotetext{
${ }^{8}$ CASTRO, Ruy (2019) p.52

${ }^{9}$ Idem p. 43/44
} 
O Rio dos anos 20, nunca teve menos de quinze ou dezesseis jornais diários circulando ao mesmo tempo. (...) Quando se falava em imprensa nacional, isso significava a imprensa carioca.

O número de revistas semanais não era menor.

Quando se atenta ao período, percebe-se, de imediato, haver uma infinidade de termos para definir estilos literários, arquitetônicos, pictóricos, decorativos, etc., em agitada convivência. Pelo o que ainda resta, no Rio de Janeiro, de construções do período ou em registros fotográficos antigos, pode-se perceber uma verdadeira "Babel" de estilos. Há desde interpretações de Luiz XV, sugestões neo-barrocas, neo-góticas, orientais, mouriscas, florentinas, normandas e, naturalmente, art nouveau. Este ganha características muito próprias por aqui. Onde, na Europa, especialmente, em Paris, se utilizava um fino trabalho de serralheria, sobretudo, nas sacadas, balcões e frontais de portarias, no Rio, confeitavam-se as fachadas com estuque.

Neste convívio carnavalizado de locações e interpretações do novo, naturalmente, que a literatura "polifonisa" também. Variadas vozes se expressam simultaneamente em diferentes registros, em variados gêneros e sotaques. Quem consegue perceber a singularidade destas vozes nos saraus literários dos salões do Rio de Janeiro é José Paulo Paes ${ }^{10}$.Em Art Nouveau na literatura brasileira, Paes avista a singularidade das peças do mosaico que representa aquele desvario novidadeiro que dialoga com os tradicionais e conservadores reminiscentes. Estes, em processo de esmaecimento, de depassement.

Acompanhando-se de perto o que é proposto por Paes ${ }^{11}$, enxerga-se com nitidez a cena Art Noveau:

Diferentemente do que costuma acontecer com as correntes inovadoras, a arte nova não se deu a conhecer por manifestos radicais ou por proclamações teóricas de caráter polêmico. Afirmou-se, antes, pela silenciosa mas eloquente atividade criadora de artistas de vários países europeus que, sem estar propriamente arregimentados num movimento ou escola, tinham em comum o empenho de reagir contra o academicismo _ em especial no campo da arquitetura e nas artes ditas aplicadas, onde campeava a imitação do gótico, do renascimento, do orientalismo _, para, com os novos materiais e as novas técnicas postos à sua disposição pelo progresso industrial, criar formas novas, em vez de copiar as antigas.

\footnotetext{
${ }^{10}$ PAES, José Paulo, O art nouveau na literatura brasileira. In: Gregos e Baianos. (1985) p. 64/80

${ }^{11}$ Idem p.65
} 
Paes, pontua que o art nouveau não é apenas um estilo de época comum às várias artes como a arquitetura, o mobiliário, a vidraçaria, a ourivesaria, o design gráfico, a ilustração, o vestuário e, naturalmente, a prosa de ficção e a poesia.

Afirma o autor ${ }^{12}$ :

\begin{abstract}
Este estilo tão expressivo da maneira de vida da belle époque se manifesta tanto nos edifícios de Horta, van der Velde ou Gaudí quanto nos desenhos de tecidos de Morris ou nos painéis decorativos de Whistler; tanto nos vasos de Gallé ou Tiffany quanto nas pinturas ou desenhos de Valloton, Munch, Klimpt, Toorop ou Beardsley; tanto nos cartazes de Tousouse- Lautrec e Mucha quanto nos móveis Mackinton e SerrurierBovy; tanto nos ornamentos de ferro de Guimard quanto na écriture artiste dos Goncourt e de Wilde ou no monismo panteísta de certos poemas de Rilke e Stefan Georg _ para citar apenas alguns dos expoentes da arte nova.
\end{abstract}

Acrescente-se, ao que Paes destaca, o excepcional trabalho de ourivesaria de tradicionais casas de joias como Cartier (1853), Lalique, Tiffany (1853) e Van Cleef \& Arpels (1906). A relevância destes se traduz, por exemplo, pelo fato de, nos Estados Unidos, se conhecer o estilo de época como Tiffany Stile. O trabalho de ourivesaria, da época, traz para o universo das joias ocidentais elementos antes desprezados como pérolas disformes (barrocas), conchas e corais esculpidos como camafeus, jade e marfim, por exemplo. São os joalheiros, assim como os escultores e oleiros que "tridimensionam" a ornamentação característica do período, onde se observa algumas recorrências de representação como insetos, especialmente, as libélulas; flores como nenúfares, copos de leite e lírios; animais como garças lânguidas e longilíneas; mulheres de cabelos esvoaçantes e Salomés com cabeleiras de cobras, seres da floresta característicos das ilustrações dos contos de fadas, entre muitas traços e formas sinuosos. Os oleiros se fazem representar nos azulejos em relevo que apresentavam os motivos acima descritos.

É curioso José Paulo Paes não citar, no fragmento acima selecionado, René Jules Lalique (1860-1945), joalheiro e vidraceiro, junto com Gallé, de peças icônicas do período. Lalique se notabilizou na confecção de frascos de perfumes e pelo uso recorrente de vidro jateado, opaco (verre sablé, em francês, ou frosted glass, em inglês) em contraste com o vidro translúcido. Além disso, seu atelier produziu espetaculares vitraux, muito usados nas construções do período. Oriundos das grandes vidraçarias, não só das francesas, como Baccarat, mas,

\footnotetext{
12 Ibidem p.66
} 
sobretudo, das oficinas artesanais da Bohemia, ocupavam lugar de realce nos salões, foyers e salas de espetáculo, os lustres de cristal. Isto porque, além de melhorar a iluminação, eram um inquestionável indicativo da moderna tecnologia da luz elétrica ${ }^{13}$.

Afora os vitrais e lustres, eram recorrentes, nas decorações Belle Époque, o uso de biombos, peças chinesas, tapeçaria oriental e tudo mais que contribuísse para oferecer um certo exotismo carnavalizado ao ambiente.

Tanto na narrativa de ficção, quanto na lírica, o universo literário se assemelhava em muito a um baile à fantasia em termos de variedades de expressão como destaca Ruy Castro ${ }^{14}$ :

$\mathrm{Na}$ ficção, havia os de todas as correntes, como os românticos tardios, os realistas, os naturalistas, os submachadianos, os regionalistas, os impressionistas, os psicologizantes e os experimentalistas. Entre os poetas, havia os líricos, os neoparnasianos, os simbolistas, os decadentistas, os penumbristas, os inconformistas e os difíceis de classificar, porque podiam ser uma mistura desses estilos ou uma negação de todos eles, Os simbolistas, por exemplo, já faziam poesia visual desde o começo do século, e o exemplo mais famoso era o poema "A Taça", de Hermes-Fontes, vazado na forma do título _ de seu livro Apoteoses,de 1908, dez anos antes da publicação dos Calligrammes, do francês Apollinaire.

José Paulo Paes ${ }^{15}$ corrobora ao pontuar:

Embora não seja fácil destacar características comuns na grande variedade de manifestações da arte nova, pode-se começar repetindo que foi a arte típica da chamada belle époque, isto é, daquele longo interregno de paz que se estendeu de 1870 até a Primeira Guerra Mundial e durante a qual prosperou uma rica sociedade burguesa, brilhante e fútil, amante do luxo, do conforto, dos prazeres, em cujas camadas mais cultas os artífices art nouveau encontraram seus clientes de eleição. Esta circunstância explica por si só o fato de o movimento renovador ter florescido especialmente no campo das artes aplicadas, assim como lhe explica o pendor para o ornamento, palavra que define in nute a sua estética. A arte nova se aproxima do barroco pela sua exuberância ornamental, no mesmo passo em que se afasta do naturalismo do século XIX, voltado antes para aspectos mais grosseiros e amiúde mais sombrios da vida cotidiana. Longe de servir de espelho às misérias do dia-a-dia, o

\footnotetext{
${ }^{13}$ Vale observar nos lustres e arandelas das construções do período (ex: Theatro Municipal do Rio de Janeiro, inaugurado em 1909) como as lâmpadas são aparentes. O intuito é deixar o mais evidente possível o uso da eletricidade.

${ }^{14}$ CASTRO, Ruy (2019) p.91

${ }^{15}$ PAES, José Paulo (1985) p.67

*Paes cita Barilli, Renato. Art Nouveau. Trad. Ingl. R. Rudorff. Feltham, Middle-sex, Paul Hasslyn, 1969, p.10
} 
art nouveau aspirava a "criar uma imagem de um mundo de beleza e felicidade universais" (Barilli)*

O mais lampejante dos escritores e intelectuais deste momento, contemporâneo e colega de redação de Figueiredo Pimentel, é, o sempre lembrado Paulo Barreto, o João do Rio. Aqui, abrimos uma exceção para atermo-nos a um escritor incensado por um segmento da crítica e, ao mesmo tempo, vítima de bulling severo, por parte de outra. Certamente, por ser obeso, mulato, dândi, homossexual e pernóstico.

Nossa atenção recai sobre ele por ser excepcional representante do caráter múltiplo de então. João do Rio era uma metralhadora giratória das letras. Paulo Barreto não assinava textos somente como João do Rio, transitava entre Máscara Negra, José Antônio José, Godofredo de Alencar, Claude, Jacques Pereira e Barão de Belfort. Em certa medida, estes "rótulos" não eram apenas pseudônimos, eram, na verdade, heterônimos, no melhor padrão pessoano, cada um com personalidade própria.

Como bem lembra Ruy Castro ${ }^{16}$ :

Um deles, Jacques Pedreira, tornou-se seu personagem de romance. Outro, Godofredo de Alencar, era citado em sua coluna social como se existisse. E o terceiro, o barão, surgia num conto como "O bebê de tarlatana rosa". Mas, por trás de todos eles, estava Paulo Barreto".

João do Rio, tinha na certidão de batismo registrado o nome: João Paulo Emílio Cristovam dos Santos Coelho Barreto. Era gordo, mulato, com olheiras muito escuras, o que conferia a seu olhar extrema profundidade, olhar de túnel, ao sabor de Theda Bara, a dramática estrela do cinema mudo. João do Rio era um dândi na mais completa acepção da palavra. Vestia-se com apuro excessivo em absoluta sintonia do que estava na moda em Paris e em Londres. É importante guardar na memória da retina esta figura chamativa, morador da Avenida Vieira Souto, quando Ipanema ainda era uma praia quase deserta, que transitava pelos mais variados ambientes da cidade. Desde sórdidos muquifos onde se fumava ópio, em becos do Centro, às alegres rodas de samba na casa de Tia Ciata, na Praça Onze, aos mais requintados salões da high Society carioca, em Botafogo, Laranjeiras e Flamengo.

\footnotetext{
${ }^{16}$ CASTRO, Ruy (2019) p.73/74
} 
João do Rio encarnava o flâneur baudleriano e, desta errância pela cidade, produzia sua prosa de ficção, as reportagens e matérias que publicava nos jornais e textos teatrais. Foi, como já dito, o primeiro repórter a sair em busca das notícias, não aguardava que chegassem à redação como era de hábito.

Em 1917, sob a liderança de Chiquinha Gonzaga, foi um dos fundadores da SBAT (Sociedade Brasileira de Autores Teatrais), junto com os mais representativos teatrólogos de então: Gastão Tojeiro, Viriato Corrêa, Oduvaldo Viana, Raul Pederneiras e Bastos Tigre.

João do Rio se enquadra em um dos segmento do art nouveau identificado como decadentismo, uma "escola" (na falta de melhor palavra) literária em que a lógica e a realidade dão lugar a um "sonho da realidade" e a "uma náusea do mundo", como observa o citado Ruy Castro, (p. 162). Para os brasileiros que se identificavam com esta corrente, segue o autor, "o decadentismo nunca lhes foi tão palpável quanto em 1916, ao assistir à última noite da bailarina americana Isadora Duncan, no Theatro Municipal.

Outros escritores brasileiros que comungam com os decadentistas são Elysio Carvalho, Alphonsus de Guimarães e Cruz e Souza. A fronteira entre decadentistas e simbolistas parece tênue, os primeiros têm como referência mater Oscar Wilde e Joris-Karl Huysmans, mas bebem também, com sede insaciável, nas fontes referenciais de simbolistas: Charles Baudelaire, Paul Verlaine, Stephane Mallarmé, Gabrielle d'Annunzio e Jean Lorrain. Parece claro que, são chamados decadentistas ou simbolistas, os escritores que se opunham aos pressupostos do realismo e naturalismo do final do século XIX. A estética decadentista brilha aos olhos quando se elege, como membro deste segmento, um artista do quilate de Luchino Visconti (1906-1976), ou melhor dizendo, Luchino Visconti di Modrone, conde de Lonate Pozzolo, um decadentista "aprés la lettre". Tanto como metteur em scene de grandes produções operísticas, quanto na direção cinematográfica, Visconti foi excepcional e único em suas montagens. Ele oferece ao público da segunda metade do século XX o fausto, o requinte, o sonho de uma realidade plena de saudades de momentos, muitas vezes, não vivenciados, tanto em suas montagens líricas quanto em suas obras cinematográficas. $O$ exemplo mais cintilante do sentido decadentista de "náusea do mundo" é sua adaptação para o cinema do romance de Thomas Mann, Morte em Veneza, em que rege o enredo, 
estabelecendo um precioso diálogo textual com a música de Gustav Mahler, mais precisamente, a $5^{\text {a }}$ Sinfonia, composta em 1901. O equilíbrio entre falas e movimentos musicais, locações no Lido de Veneza, movimentação de personagens, luz, paleta cromática e figurinos, nos dá a medida certa de uma idealização Belle Époque.

Uma representante destacada de nossas letras, neste período, que, sabese lá por que razão, foi escondida por uma burca crítica, é Júlia Lopes de Almeida. Além de ser uma das mais destacadas anfitriãs dos salões literários realizados na cidade, era um fenômeno editorial. Conta-nos Ruy Castro ${ }^{17}$ :

\begin{abstract}
Desde sua estreia, em 1886, aos 23 anos, publicara mais de quarenta livros, incluindo nove romances, cinco livros de contos, um de novelas, outro para crianças e cinco de teatro, além de livros de viagem, jardinagem, memórias, conselhos para noivas e outros gêneros. Exceto Coelho Netto, ninguém chegava perto dela em produtividade. (...) Ela tinha o público e nunca precisou sair de sua estética naturalista, herdada de Zola, Eça e Maupassant. Neste sentido, era uma escritora do começo do século, mas seus leitores não se queixavam _ porque eles também o eram. Entre um livro e outro, Júlia encontrava tempo para viajar dentro e fora do Brasil, dar conferências, escrever crônicas para Gazeta de Notícias, o Jornal do Comércio e O País, e para revistas como Kosmos, O Mundo Literário e Ilustração Brasileira, e ainda cuidar do jardim, da casa, dos filhos e do marido.
\end{abstract}

Júlia era, ao mesmo tempo, uma grande dama e uma contestadora republicana, abolicionista e anticlerical. Os temas de suas crônicas, nas páginas diárias, versavam sobre educação, violência policial, desmatamento e desigualdade social, temas, absolutamente, contemporâneos.

Seus romances traziam, com frequência, personagens femininas sufocadas pelo casamento, em busca de independência, adúlteras conscientes e "até mãe e filha em luta pelo mesmo homem"18. Julia despertara cedo para a situação da mulher.

Julia casou-se, em 1888, com o poeta Filinto de Almeida, cujo brilho era quase imperceptível se comparado ao dela. Ela foi uma das mais penhoradas intelectuais na fundação da Academia Brasileira de Letras, junto com Machado de Assis e Lucio de Mendonça, em 1897. Só não foi eleita por ser mulher. Mulheres

\footnotetext{
17 Idem p.63/64

18 Ibidem p.64
} 
não faziam parte do panteão dos imortais. Como prêmio de consolação, elegeram o seu parnasiano marido, Filinto, como acadêmico.

Espaços importantes na sociabilidade dos artistas e escritores, no Rio de Janeiro da passagem do século, eram os Cafés, como indica Brito Broca ${ }^{19}$ :

\begin{abstract}
Os principais cafés "literários" do Rio são, entre outros, os da última década do século 19, do período áureo da boêmia: o Café do Rio no cruzamento da Rua do Ouvidor com a Rua Gonçalves Dias; o Java, no Largo de São Francisco, esquina com Ouvidor; o Café Paris, o Café Papagaio; Café Globo, na rua Primeiro de Maio entre Ouvidor e o Beco dos Barbeiros, em cujos altos existe um tradicional restaurante já em decadência por volta de 1901.
\end{abstract}

Pontos igualmente preferidos pelas celebridades literárias: Confeitaria Colombo, na rua Gonçalves Dias e a Confeitaria Pascoal, na rua do Ouvidor, (...).

Os salões literários tinham um lugar de relevo no universo das artes. As senhoras da sociedade, proprietárias dos palacetes de Botafogo, Flamengo e Laranjeiras, e alguns escritores consagrados promoviam encontros semanais. A fronteira entre salões literários e salões mundanos era quase imperceptível. Havia um número expressivo de encontros onde, especialmente, as moças e senhoras apresentavam-se ao piano. Havia pianos na maioria das casas, tanto que, Araújo Porto-Alegre, chamava a então capital de "a cidade dos pianos". Recitavam-se poemas, cantavam-se peças populares e clássicas, liam-se fragmentos de obras inéditas e, sobretudo, os participantes expunham seus conhecimentos e personalidades para o conhecimento dos outros. Era de bom tom, os anfitriões saberem dosar a presença de consagrados com novatos o que nem sempre era possível já que muitas das reuniões eram no sistema de "open house". Face ao grande número de salões, selecionamos dois que parecem oferecer a temperatura desses encontros, um, mais literário, o de Coelho Netto e outro, mais mundano, mas, não menos artístico, e que tinha como anfitriã, a "marechala" da alta sociedade da época, Laurinda Santos Lobo.

Brito Broca ${ }^{20}$ informa:

\footnotetext{
${ }^{19}$ BROCA, Brito (1975) p.33

${ }^{20}$ Idem p.26/27

*O autor refere-se ao salão de Laurinda Santos Lobos a que iremos nos ater a seguir.
} 
O famoso salão de Coelho Neto, na Rua do Rozo, não possuía o mesmo cunho de alto mundanismo*, esse tom afetado e esnobe. Ali predominava a literatura, a cordialidade, e até uma certa sem-cerimônia. A casa de dois andares, com um jardim ao lado, estava sempre aberta a todo mundo, aos plumitivos que vinham dos pontos mais distantes da província, com um manuscrito ou uma carta de apresentação para o escritor, cuja fama corria - Brasil inteiro. As duas primeiras décadas do século foram, por excelência, o período do apogeu de Coelho Netto, quando exerceu ele sensível influência em nossas letras, aclamado não somente aqui como em Portugal. Aliás, alguns de seus melhores livros, Turbilhão, Treva, apareceram nesta época. Martins Fontes chamava a residência da Rua do Rozo de "Santa Casa de Coelho Netto", pela franqueza generosa com que o escritor acolhia a todos, estimulando-os, entusiasmando-os, distribuindo elogios com a maior facilidade. "A grande mesa de jacarandá ao centro, os armários manuelinos, pejados de bons livros camilianos; o pequeno ramo de salgueiro do túmulo de Musset, colhido pelo mestre; os estudos de Antônio Parreiras; os bibelôs; um busto de Eça de bronze, de expressão surpreendente, e pairando sobretudo, dando valor a tudo, a graça sem par de Dona Gaby" _ eis como retrata o ambiente o cronista Benetito Costa.

As reuniões se davam geralmente aos sábados. Pelos corredores, nas salas e no jardim cruzavam-se figuras da novae da velha geração: Oscar Lopes, Fernando Guerra Durval, Gustavo Barroso, Olegário Mariano, Jorge Jobim, gregório da Fonseca, João Luso, Alberto de Oliveira, e mais Álvaro Moreyra, Felipe d'Oliveira, Humberto de Campos, Anibal Teófilo, tantos outros, sem falar em Olavo Bilac, o velho companheiro, o "suave Bilac", como o denominara Coelho Neto (...) Não eram só escritores: pianistas, violinistas, cantores moços e velhos, escultores, mestres e alunos da Escola de Belas Artes, iam também à Rua do Rozo (...) Eleito "príncipe dos poetas", Bilac foi ali coroado numa noite festiva e inesquecível (...).

Pela descrição de Brito Broca, pode-se aquilatar a importância destes encontros no que concerne à dinâmica social do universo artístico e intelectual carioca, na Belle Époque.

Não é raro, entre as grandes fortunas do Rio de Janeiro, do passado, se encontrar casos de sócios nos negócios que acabavam por se associar familiarmente. Isto é, histórias de ménage à trois. Assim era constituído o núcleo familiar que vivia sob o teto do Palacete Murtinho, construído entre 1898 e 1902, no bairro de Santa Teresa, o Montmartre carioca. Hoje, funciona ali um centro cultural municipal que leva o nome de sua antiga proprietária, Laurinda Santos Lobo. Foram aproveitadas as ruinas da antiga construção para erguer um prédio arrojado no nobre terreno, chamado pelo público de Parque das Ruinas.

O palacete era propriedade de Joaquim Murtinho, um milionário, dono de grandes extensões de terras em Minas Gerais, Mato Grosso, Goiás e no Rio de Janeiro. Ele fora ministro da Fazenda de Campos Salles. Era engenheiro e o 
médico que introduziu a homeopatia no Brasil. Joaquim era tio de Laurinda. Ela era casada com Hermenegildo Santos Lobo, um rico atacadista de tecidos, mas cuja fortuna pouco significava se comparada à que Laurinda herdara. Dormiam em quartos separados, raramente eram vistos juntos e muitos pensavam ser ela viúva (o que de certa forma era meio verdadeiro já que o tio falecera).

Laurinda não gozava de grande beleza, esta era compensada por seu extraordinário savour fair e incomparável allure. Aos 33 anos, assumiu o comando do palacete e o rebatizou com seu nome. O tio faleceu em 1911, aos 63 anos de idade, fazendo dela a herdeira universal de incalculável fortuna. Passado o luto, reabriu os salões e passou a misturar com os frequentadores tracionais, amigos do tio, uma fauna de artistas. E logo o palacete passou a ser identificado por toda a cidade com o nome da nova proprietária.

Detalha Ruy Castro'21:

Ela o rebatizou como Palacete Santos Lôbo, continuou com as recepções e, sem perder os habitués de seu tio, misturou-os a romancistas, poetas, compositores, pintores, caricaturistas e até jornalistas.

(....)

E era da Europa que vinham esses convidados: o próprio Anatole France; os dançarinos Isadora Duncan, Nijinsky e Anna Pavlova; o pianista Arthur Rubinstein; o compositor e maestro Richard Strauss; os tenores Enrico Caruso (...) e artistas brasileiras consagradas lá fora, como a pianista Magdalena Tagliaferro e as sopranos Vera Janacópulos e Bidú Sayão. E, entre os convidados nacionais, contavam-se João do Rio, os romancistas Graça Aranha e Afrânio Peixoto,o poeta Ronald de Carvalho, o casal Eugênia e Idemas áreas. Villa-Lobos custou a ser admitido, mas só enquanto não era reconhecido. Assim que isso aconteceu, ficou tão íntimo de Laurinda que passou a se confundir com a decoração da casa.

É importante mencionar que, nos salões de Laurinda, convergiam os artistas que se identificavam com os pressupostos do Modernismo que se anunciava desde os primeiros anos da década de 1910.

Havia, no Rio de Janeiro, afora os salões, restritos aos iniciados, uma infinidade de agremiações, clubes, associações em que se realizavam encontros com escritores, Entre os anos de 1900 e 1910 era muito frequente a realização de conferências pagas.

\section{Conta-nos Ruy Castro 22 :}

${ }^{21}$ CASTRO, Ruy (2019) p. 61-63

${ }^{22}$ Idem p.91 


\begin{abstract}
A moda (...) começara nos auditórios do Clube dos Diários e do Teatro Palace, ambos na rua do Passeio, e no Teatro Lyrico, no largo da Carioca. No passado, essas conferências eram eventos pomposos, por pesos pesados como Coelho Netto, Olavo Bilac ou Luiz Edmundo, com a leitura de tratados sobre as altas funções da literatura, como o tempo, passaramse para os clubes esportivos e agora tratavam de abstracões, como o Amor, a Solidão, a Felicidade _ assim mesmo, com maiúsculas _, tendo como praticantes os versáteis e espertos Humberto de Campos, Bastos Tigres e Medeiros e Albuquerque, Casais ambiciosos, ansiosos por se fazer notar socialmente e ter seus nome nos jornais, contratavam os escritores para repetir em suas casas a gordo cachês, as conferências que já haviam dado alhures. Surgiu então uma variante do gênero: as conferências humorísticas, em que, no palco, o causeur _ um escritor_ descompunha políticos, governadores ou personalidades, e um caricaturista produzia uma charge ao vivo, diante da plateia, desenhandoos num grande bloco de papel.
\end{abstract}

Já foi observado anteriormente o lugar de relevo que os caricaturistas ocupavam então, especialmente, em razão de as ilustrações se fazerem acompanhar de uma legenda ou mesmo de um pequeno texto da lavra dos próprios desenhistas, muitos deles também escritores. Não havia jornal que não tivesse em seus quadros um ou mais caricaturistas. Eram eles Raul Pederneiras, Calixto, Luiz Peixoto, Vasco Lima e, certamente, o maior de todos, J. Carlos. Ele revolucionou a caricatura no Brasil. Era muito além de um caricaturista, foi cenógrafo, e mais que tudo, um inigualável artista gráfico, designer e figurinista. É quem concebe a melindrosa que, antes da Garota de Ipanema, figurava como a representação máxima da mulher carioca urbana moderna, smart, exemplo a ser seguido pelas brasileiras "civilizadas", como queria Figueiredo Pimentel.

Sempre é difícil se tentar criar um panorama de períodos criativos e plurais como também o é a organização de antologias uma vez que os critérios de seleção dos fatos ou dos textos são sempre de cunho pessoal. Há, no entanto, determinados acontecimentos e textos basilares que não podem ficar de fora das seleções. Por exemplo, o que parece mais relevante: $O$ fato de Oswald de Andrade ter sido um fã incondicional dos parnasianos e, por volta de 1910, estar sempre no Rio de Janeiro, atrás de Emílio de Menezes, e com ele aprender os poemas piada que o notabilizariam no modernismo, sem nunca dar crédito ao mestre, mas, o contrário disto, chamá-lo, anos mais tarde, de "palhaço da burguesia"? Ou seria 
mais apropriado dar visibilidade à expressão popular que efervescia na cidade naquela passagem de século? A escolha recaiu sobre a segunda opção.

A passagem do século é o momento de fixação do chorinho, uma forma de tocar que se torna um gênero musical. O choro é, por muitos, considerado como a primeira música urbana brasileira. De seu berço de criação faziam parte músicos das bandas militares, de corporação de trabalhadores e avulsos. Mas, tudo gente que lia pentagrama. Da mesma forma, e daí o perigo de se dizer ser o primeiro gênero urbano, nasceu o frevo, no Recife, também entre o final do século XIX e início do XX, e, igualmente, entre músicos das bandas militares e de corporações de trabalhadores. Também, no universo do frevo é impossível afirmar-se o que surgiu primeiro, a dança ou o ritmo? O mais correto é se afirmar, neste caso, que a dança dos capoeiras, que acompanhavam as apresentações das bandas, acabou por influenciar o andamento do dobrado executado, fazendo com que nascesse um ritmo novo.

Pixinguinha, por exemplo, é músico e compositor nascido em roda de choro, cujas origens estilísticas, ou raízes, estão na fina mistura entre o lundu, de origem africana, especialmente, sua base percussiva, e os ritmos europeus. A composição instrumental dos primeiros grupos era formada pelo trio flauta, violão e cavaquinho, formação também chamada de pau e corda.

Os primeiros conjuntos de choro surgiram por volta da década de 1870, nascidos nas biroscas do bairro Cidade Nova e nos quintais dos subúrbios cariocas. O flautista e compositor Joaquim Antônio da Silva Calado, os pianistas Ernesto Nazareth e Chiquinha Gonzaga ${ }^{23}$, e o maestro Anacleto de Medeiros compuseram quadrilhas, polcas, tangos, maxixes, xotes e marchas, estabelecendo os pilares do choro e da música popular carioca da virada do século XIX para o século XX. Herdeiro de toda essa tradição musical, Pixinguinha consolidou o choro como gênero musical, levando o virtuosismo na flauta e aperfeiçoando a linguagem do contraponto com seu

${ }^{23}$ Chiquinha Gonzaga, além de maestrina, arranjadora, compositora, criadora da SBAT (Sociedade Brasileira de Autores Teatrais), é considerada a primeira compositora de música de carnaval. O seu Abre Alas, composto por encomenda do Cordão Rosa de Ouro, em 1899, é o marco da música carnavalesca brasileira. Também é ela a responsável pela divulgação do choro no seio das elites (ela levou seu Corta Jaca ou Gaúcho, ao Palácio do Catete, em 1914, em sarau promovido pela revolucionária Primeira Dama, Nair de Tefé, a caricaturista Rian, provocando um verdadeiro escândalo). Foi ela também uma das responsáveis pela introdução, nos salões, do violão, instrumento considerado marginal naquele tempo. 
saxofone. Foi o responsável pela organização de inúmeros grupos musicais, tornando-se o maior compositor de choro. Sempre perigoso dizer-se "o maior", mas neste caso, foi o compositor, que, pela vivência, teve a oportunidade de melhor conhecer os meandros, as vísceras do gênero. A grande fascinação deste momento de formação é se perceber, claramente, como a música das elites absorve, de forma voraz, elementos da música popular e como esta se alimenta das novidades da cultura dominante entre as elites.

Paralelo ao choro, no Rio de Janeiro, vai se consolidando o samba, ritmo que viria a ser usado pelo Estado Novo, na década de 1930, como trilha sonora da política populista de Vargas. O samba é, então , alçado à categoria de "o" gênero musical genuinamente brasileiro, com vistas a aproximar o morro com o asfalto para fixar as leis trabalhistas, assim, substituindo a mítica figura do malandro buliçoso em apaziguado trabalhador.

Convencionou-se atribuir, ao samba carioca, residência fixa, a casa de Tia Ciata. Isto porque, o samba nasce na Cidade Nova, na Praça Onze, para onde migraram os cativos libertos, especialmente, os vindos da Bahia. O sambista Heitor dos Prazeres foi quem batizou a região de Pequena África, nome usado no livro Tia Ciata e A Pequena África, texto icônico sobre a origem do samba, de autoria de Roberto Moura (1983).

Foi na casa das tias baianas, quase todas ialorixás, ou iniciadas no universo dos Orixás, que o samba carioca ganhou fisionomia própria, espacialmente, na casa de Ciata. Hilária Batista de Almeida (Santo Amaro da Purificação (BA), 1854 - Rio de Janeiro (1924), foi uma quituteira, e, mais que tudo a anfitriã do samba. Em sua casa da Praça Onze se reuniam os sambistas, como mencionado no início, nasceu Pelo Telefone (1916), e era onde os intelectuais, como João do Rio entre muitos outros, músicos, como Villa-Lobos, se encontravam. A Praça Onze, era o espaço de convergência do carnaval popular, lá nasceu o desfile das escolas de samba. Não só da comunidade afrodescendente buscava moradia e acolhida na Cidade Nova, como se chamava a região, mas também imigrantes estrangeiros, comerciantes judeus e árabes ${ }^{24}$.

\footnotetext{
${ }^{24}$ Ainda que Ciata seja conhecida por registros, não há imagens dela, só se sabe como era por depoimentos de seus contemporâneos. Há dois livros de autoria de Nei Lopes Mandinga de Mulata Velha na Cidade Nova. Rio de Janeiro: Língua Geral .2009 e O Preto que falava Íldiche. São Paulo:
} 
Uma outra figura que merece aqui registro e, como Ciata, teve papel relevante no contexto das festas e celebrações populares foi Hilário Jovino Ferreira, o Lalau de Ouro, (Pernambuco, 1873 -Rio de Janeiro, 1933) compositor, letrista e agitador cultural, pioneiro do samba e do carnaval. Ele foi responsável por levar para o espaço carnavalesco os ranchos, originalmente, natalinos. Foi o fundador do "Rei de Ouros", daí ser conhecido com Lalau do Ouro. Foi o responsável por apresentar novidades como o enredo, nos desfiles, e o uso de instrumentos de cordas e de sopro, além de personagens como o casal de mestre-sala e portabandeira e pastoras (que se transformaram em passistas) oriundos do rancho natalino.

Neste "vitral" da cultura art nouveau carioca procurou-se contemplar as diferentes nuances desta rica paleta cultural da passagem do século XIX para 0 $X X$, em que aparecem personagens de extraordinária originalidade, mas que, nem sempre a crítica desvela e a história recobre com a pátina do tempo.

\section{Referências}

ALMEIDA, Júlia Lopes. Ânsia Eterna. Rio de Janeiro: Vermelho Marinho.2019.

BOUÇAS, Edmundo \& GÓES, Fred. As Melhores Crônicas de João do Rio. São Paulo: Ed. Global, 2009.

BROCA, Brito. A vida Literária no Brasil - 1900. Rio de Janeiro: José Olympio, 1975.

CASTRO, Ruy. Metrópole à beira-mar: o Rio moderno dos anos 20. Saõ Paulo: Companhia das Letras, 2019.

COUTINHO, Eduardo Granja. Os Cronistas de Momo: imprensa e carnaval na Primeira República. Rio de Janeiro: Ed. UFRJ, 2006.

DIDIER, Carlos. Orestes Barbosa: repórter, cronista e poeta. Rio de Janeiro: Agir, 2005.

MARTINS, Wilson. A Ideia Modernista. Rio de Janeiro: ABL \& Topbooks, 2002.

MENDES, L. \& CATARINA, Pedro Paulo. Figueiredo Pimentel, um polígrafo da Belle Époque. São Paulo: Alameda, 2019.

Record, 2018. Que retratam com grande riqueza de detalhes a vida naquela região do centro carioca. 
MOURA, Roberto. Tia Ciata e a Pequena África. Rio de Janeiro: Funarte, 1983.

PAES, José Paulo. Gregos \& Baianos. São Paulo: Brasiliense, 1985.

PIMENTEL, Figueiredo. Binóculo. Gazeta de Notícias. Rio de Janeiro 8/03/1908.

SÜSSEKIND, Flora. Tal Brasil, Qual Romance? Rio de Janeiro: Achiamé, 1984.

OLIVEIRA, Claudia et alli. O modernismo em Revista, representações do Rio de Janeiro de 1890 a 1930. Garamond, 2010. 